\author{
SŁaWomir Dorocki, Anna Irena SzymańsKa, \\ MalgorZata Zdon-KorZENIOWSKA \\ Uniwersytet Pedagogiczny, Kraków, Polska
}

\title{
Przedsiębiorstwa agroturystyczne w gospodarce opartej na wiedzy
}

\section{Agritourism Enterprises in a Knowledge-based Economy}

\begin{abstract}
Streszczenie: Przedsiębiorstwa agroturystyczne są istotną gałęzią aktywności gospodarczej zarówno w skali lokalnej, krajowej, jak i międzynarodowej. Agroturystyka stanowi ważną formę dywersyfikacji działalności gospodarstw rolnych (pod terminem „dywersyfikacja” należy rozumieć wykorzystanie środków, jakimi dysponuje gospodarstwo rolne na prowadzenie działalności niezwiązanej z rolnictwem; Kłodziński, 2001). Odgrywa ona istotną rolę w aktywizacji gospodarczej obszarów wiejskich, wpływa na lokalne struktury gospodarcze i ich ożywienie, a w efekcie przyczynia się do wzrostu liczby miejsc pracy i pozyskiwania nowych źródeł dochodu.

Zasadniczym celem niniejszego artykułu jest diagnoza stanu przedsiębiorstw agroturystycznych w Polsce, ze szczególnym uwzględnieniem charakterystyki i określenia struktury oferty tych przedsiębiorstw, oceny ich zachowań rynkowych, przedsiębiorczych i innowacyjnych w gospodarce opartej na wiedzy. Podstawę analizy stanowią zarówno informacje pochodzące ze źródeł wtórnych, jak i bezpośrednie badania kwestionariuszowe oraz indywidualne wywiady pogłębione, przeprowadzone na próbie gospodarstw agroturystycznych funkcjonujących na terenie całej Polski.
\end{abstract}

\begin{abstract}
Agritourism enterprises represent an important branch of economic activity on the local, national and international scale. Agritourism is a significant form of farm activities diversification (Kłodziński, 2001). It plays crucial role in the economic revival of rural areas, affects the local economic structures and their liveliness, and in the consequence contributes to an increase in the number of workplaces and attracting new sources of income.

The main objective of this paper is the diagnosis of agritourism enterprises in Poland. It focuses on the characteristics and structure determining of agritourism farms offer, as well as evaluating entrepreneurial, innovative and market behaviour of agritourism enterprises in a knowledge-based economy. The basis for the analysis is formed on both the information from secondary sources as well as surveys and individual in-depth interviews conducted with a sample of agritourism farms throughout Poland.
\end{abstract}

Słowa kluczowe: agroturystyka; gospodarka oparta na wiedzy; innowacyjność; przedsiębiorstwa agroturystyczne

Key words: agritourism; agritourism enterprises; innovativeness; knowledge-based economy 


\section{WPROWADZENIE}

Wiedza jest zasobem, który współcześnie nabiera coraz większego znaczenia w rozwoju gospodarki. Rośnie rola kapitału ludzkiego i innowacji, a „świat wkroczył w epokę, w której umiejętność pozyskiwania i przetwarzania informacji oraz tworzenia wiedzy stają się podstawą sukcesu ekonomicznego" (Fic, 2005). Całość dostępnej współcześnie wiedzy podwaja się mniej więcej co pięć lat, a czas owego podwajania systematycznie się skraca. Ogromny wpływ na szybkość gromadzenia, przetwarzania i przekazywania informacji wywiera rozwój technologii informacyjnych i komunikacyjnych. Naukowcy coraz częściej zadają pytanie, na jakim etapie przejścia z gospodarki przemysłowej do gospodarki opartej na wiedzy znajduje się współczesna gospodarka.

Gospodarka oparta na wiedzy (GOW, ang. the knowledge-based economy) bazuje na wiedzy i informacji, której podstawę stanowią zaawansowane technologie oraz branże, w których angażowani są wykwalifikowani pracownicy (Borowiec, Dorocki, Jenner, 2009).

W literaturze przedmiotu pojęcie gospodarki opartej na wiedzy jest w różny sposób definiowane i rozumiane. Zgodnie z definicją Z. Chojnickiego i T. Czyż (2007: 423), gospodarka oparta na wiedzy ,stanowi typ gospodarki, której rozwój i przekształcenia dokonują się pod dominującym wpływem nauki. Oddziaływanie postępu naukowego staje się głównym czynnikiem rozwoju gospodarki, znacznie przeważającym nad innymi czynnikami”. Przyjmując takie ujęcie GOW, można powiedzieć, że tworzy ona skomplikowany układ wzajemnych oddziaływań pomiędzy wiedzą i gospodarką. W literaturze przedmiotu zazwyczaj wymienia się cztery filary tworzące gospodarkę opartą na wiedzy (Niklewicz-Pijaczyńska, 2011: 444-445):

- system innowacyjności firm,

- edukację i szkolenia,

- technologie informacyjne i komunikacyjne,

- bodźce ekonomiczne i porządek instytucjonalny.

Często wymienia się także piąty filar, jakim jest kształcenie ustawiczne.

Można tu zadać pytanie, jak we współczesnej, gwałtownie zmieniającej się gospodarce radzą sobie polskie gospodarstwa agroturystyczne, stanowiące główny przedmiot rozważań w niniejszym artykule. Czy zmiany te wpływają na ich rozwój? Czy gospodarstwa potrafią wykorzystać wiedzę jako źródło tworzenia przewagi konkurencyjnej na rynku? W jakim stopniu stosują one zaawansowane technologie informatyczne i komunikacyjne?

\section{Gospodarstwa agroturystyczne w Polsce}

Gospodarstwa agroturystyczne stanowią ważną gałąź aktywności gospodarczej zarówno w skali lokalnej, krajowej, jak i międzynarodowej. Agroturystyka pełni istotną rolę w aktywizacji gospodarczej obszarów wiejskich i przyczynia się do wzrostu liczby miejsc pracy i pozyskiwania nowych źródeł dochodu. 
W niniejszym artykule zdiagnozowano stan przedsiębiorstw agroturystycznych w Polsce. Dokonano charakterystyki struktury oferty tych przedsiębiorstw, oceny ich zachowań rynkowych, przedsiębiorczych i innowacyjnych w gospodarce opartej na wiedzy. W badaniach wykorzystano zarówno informacje pochodzące ze źródeł wtórnych, jak i bezpośrednie badania kwestionariuszowe przeprowadzone na dobranej losowo próbie gospodarstw agroturystycznych funkcjonujących na terenie całej Polski. Podstawę analiz stanowiły 1682 profile polskich gospodarstw agroturystycznych zrzeszonych i rekomendowanych przez Polską Federację Turystyki Wiejskiej „Gospodarstwo Gościnne” oraz 64 profile gospodarstw agroturystycznych, opracowane w efekcie badań kwestionariuszowych.

Analiza zarówno zgromadzonego materiału statystycznego, jak i literatury przedmiotu umożliwiła wyodrębnienie czterech podstawowych grup czynników oddziałujących na rozwój agroturystyki w Polsce (ryc. 1) w warunkach gospodarki opartej na wiedzy. Należy tu wymienić przede wszystkim:

1. Potencjał turystyczny obszarów wiejskich: walory przyrodniczo-kulturowe, zagospodarowanie turystyczne, warunki ekonomiczne i infrastrukturalne.

2. Zmiany potrzeb, preferencji, modelu i stylu życia „społeczeństwa informacyjnego": formy spędzania wolnego czasu, sposoby organizacji wypoczynku, zmiany / nowe kierunki wyjazdów, wybór określonych dóbr i usług turystycznych. Na zmianę potrzeb, preferencji, modelu i stylu życia ,społeczeństwa informacyjnego" wpływają takie determinanty jak: struktura demograficzno-ekonomiczna społeczeństwa (np. wiek, płeć, miejsce zamieszkania, wykształcenie, poziom dochodu), uwarunkowania kulturowe (np. przynależność do określonej kultury, subkultury), uwarunkowania psychologiczne (np. osobowość, motywacje, innowacyjność) oraz uwarunkowania społeczne (m.in. faza cyklu życia rodziny, grupy odniesienia).

3. Procesy globalizacyjne i integracyjne, a w ich ramach: postępująca liberalizacja przepływu osób, towarów i usług, szybki postęp techniczny i technologiczny (m.in. transport, komunikacja), dotacje Unii Europejskiej, sprzyjające rozwojowi działalności agroturystycznej oraz trwający od 2008 roku światowy kryzys gospodarczy, oddziałujący na ubożenie społeczeństwa.

4. Uwarunkowania formalno-organizacyjno-prawne rozwoju rolnictwa oraz przedsiębiorczości na terenach wiejskich w danym kraju, a wśród nich w szczególności: struktura i wielkość gospodarstw rolnych oraz formy gospodarowania, struktura własnościowa gospodarstw rolnych, system wspierania przedsiębiorczości i przedsiębiorczość społeczności lokalnej. Powyższe ma wpływ na genezę prowadzonej działalności agroturystycznej - gospodarstwa agroturystyczne mogą powstawać bowiem na fundamencie wcześniej prowadzonej innej działalności pozarolniczej, z przekształcenia gospodarstwa rolnego lub gdy w gospodarstwie od początku prowadzona jest działalność agroturystyczna.

Złożoność problematyki uwarunkowań rozwoju agroturystyki w Polsce w gospodarce opartej na wiedzy sprawia, że w dalszej części artykułu poruszone zostaną jedynie wybrane aspekty tego zagadnienia. 


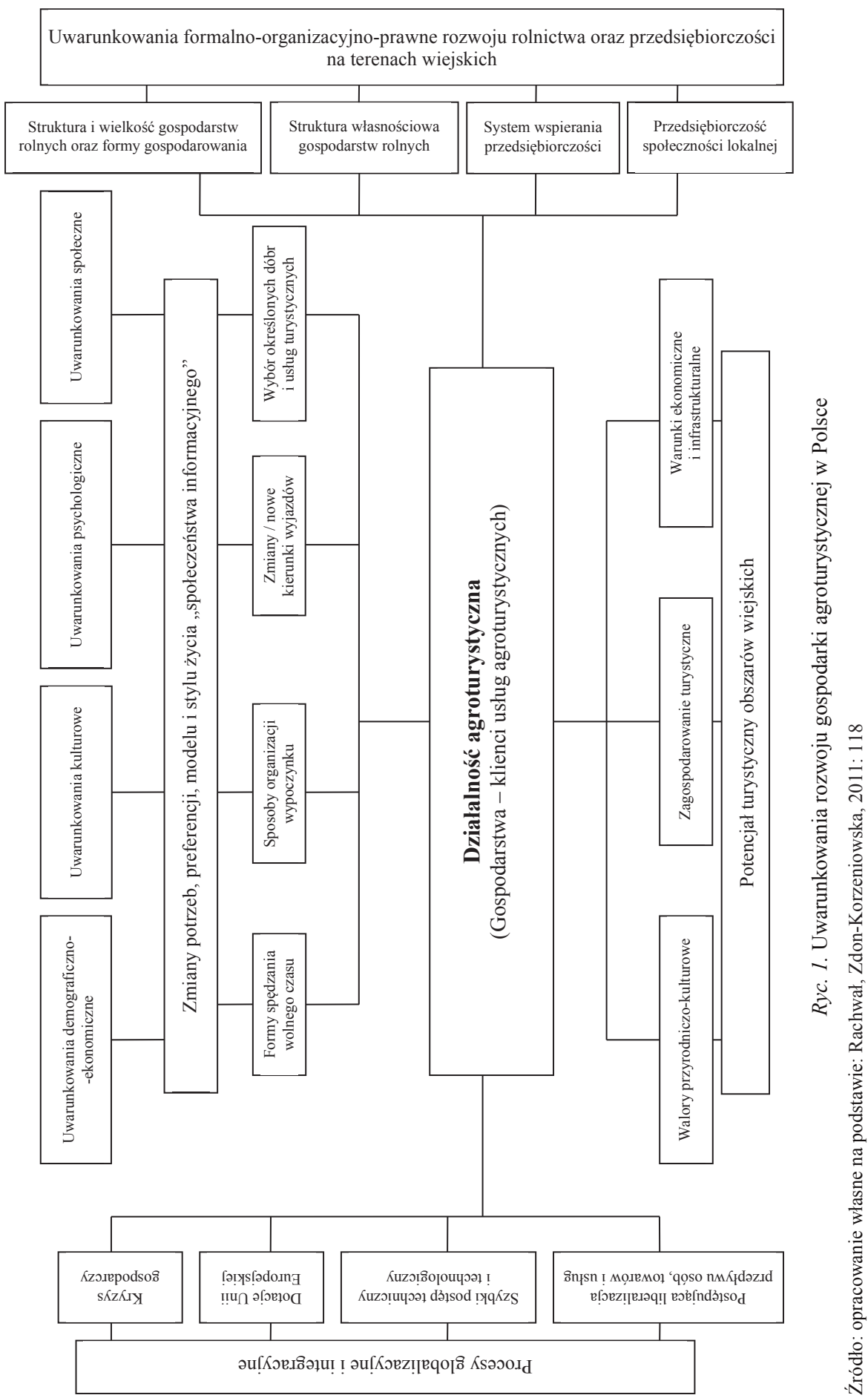




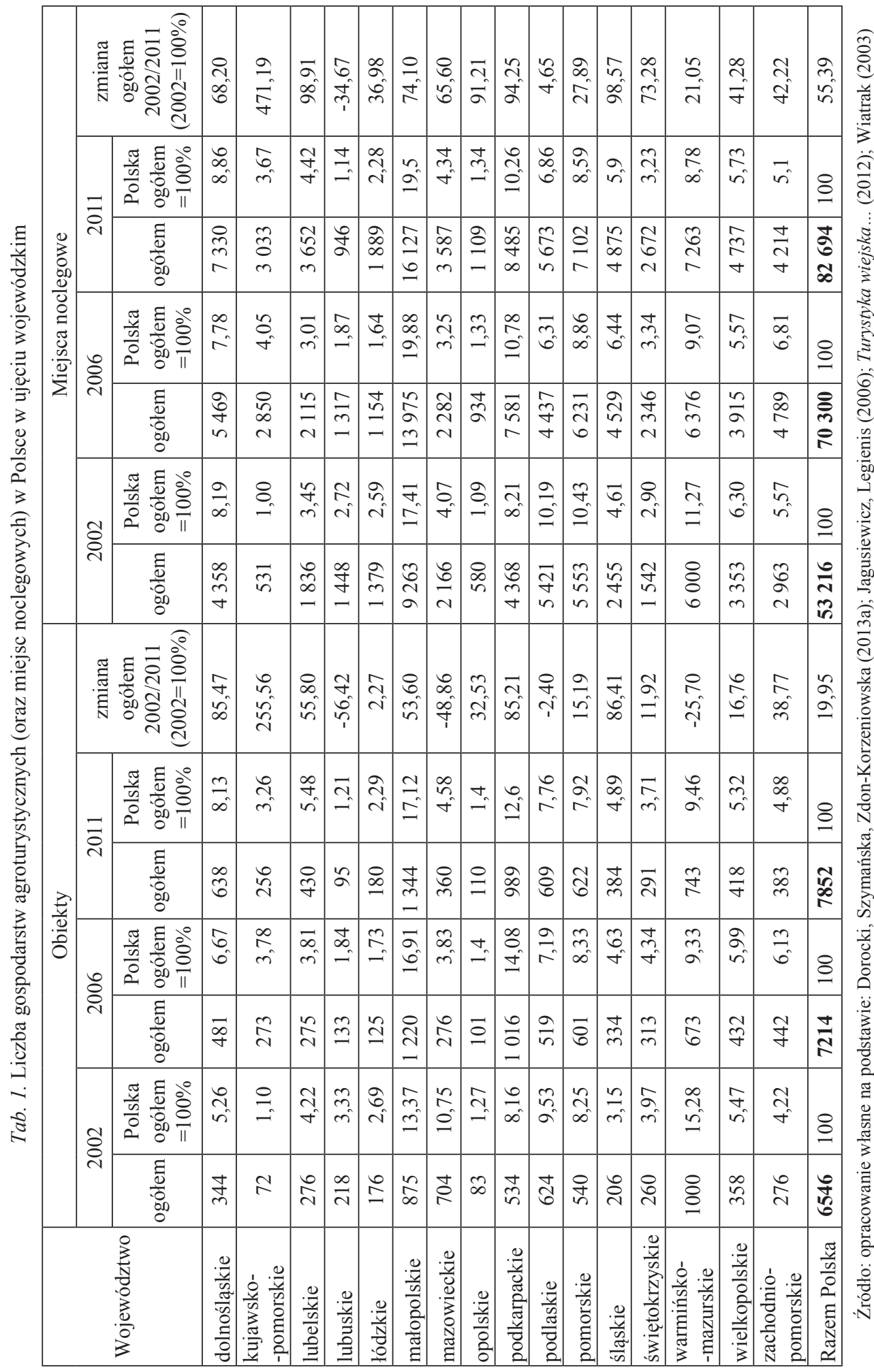


Zebrane za lata 2002, 2006 i 2011 dane wskazują na stały wzrost liczby gospodarstw agroturystycznych w Polsce. W 2011 roku funkcjonowały około 7852 gospodarstwa agroturystyczne, oferujące łącznie 82694 miejsca noclegowe, co stanowiło prawie 20\% wzrost liczby gospodarstw agroturystycznych i niemal 55\% wzrost liczby miejsc noclegowych w stosunku do 2002 roku (Dorocki, Szymańska, Zdon-Korzeniowska, 2013a). W tabeli 1 zawarto zestawienie liczby obiektów agroturystycznych i oferowanych miejsc noclegowych w poszczególnych województwach oraz zmiany ilościowe z uwzględnieniem wymienionych lat.

Analiza genezy gospodarstw agroturystycznych, oparta na wynikach przeprowadzonych bezpośrednich badań kwestionariuszowych, wykazała, że ponad $67 \%$ badanych przedsiębiorstw agroturystycznych powstało z przekształcenia gospodarstwa rolnego. W przypadku ponad 17\% podmiotów prowadzona była wcześniej inna działalność pozarolnicza, zaś około $15 \%$ gospodarstw od początku działało jako gospodarstwa agroturystyczne.

Na potrzeby prowadzonych badań dokonano prezentacji przestrzennego rozmieszczenia gospodarstw agroturystycznych w Polsce (ryc. 2). Lokalizacja poszczególnych gospodarstw agroturystycznych została dokonana w oparciu o ich współrzędne geograficzne (namiary GPS i kody pocztowe).

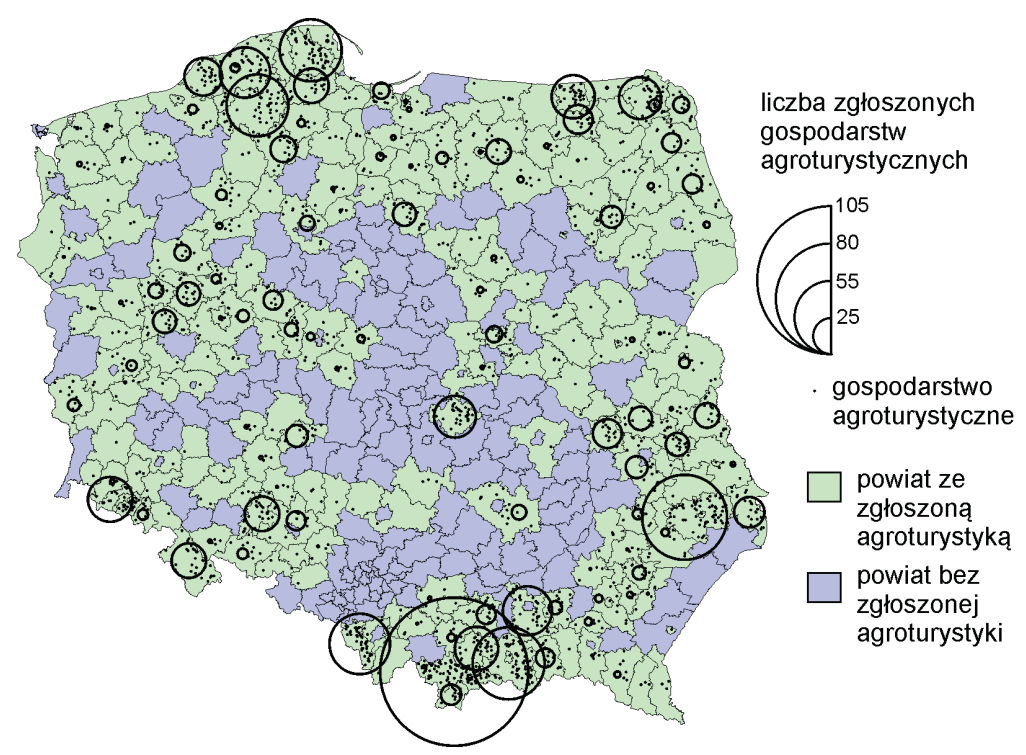

Ryc. 2. Przestrzenny rozkład badanych gospodarstw agroturystycznych w Polsce

Źródło: Dorocki, Zdon-Korzeniowska (2012)

Analiza zgromadzonych danych wykazała, że gospodarstwa agroturystyczne zazwyczaj zlokalizowane są na terenach charakteryzujących się dużą atrakcyjnością turystyczną, jak również utrwalonymi tradycjami obsługi ruchu turystycznego (np. obszary nadmorskie, górskie, pojezierza). Często są to również obszary słabo zurbanizowane i nieuprzemysłowione (Sikora, 2012), obszary chronione lub charakteryzujące się niekorzystnymi warunkami gospodarowania (niska jakość gleb, niekorzystne ukształtowanie terenu; ryc. 3). 

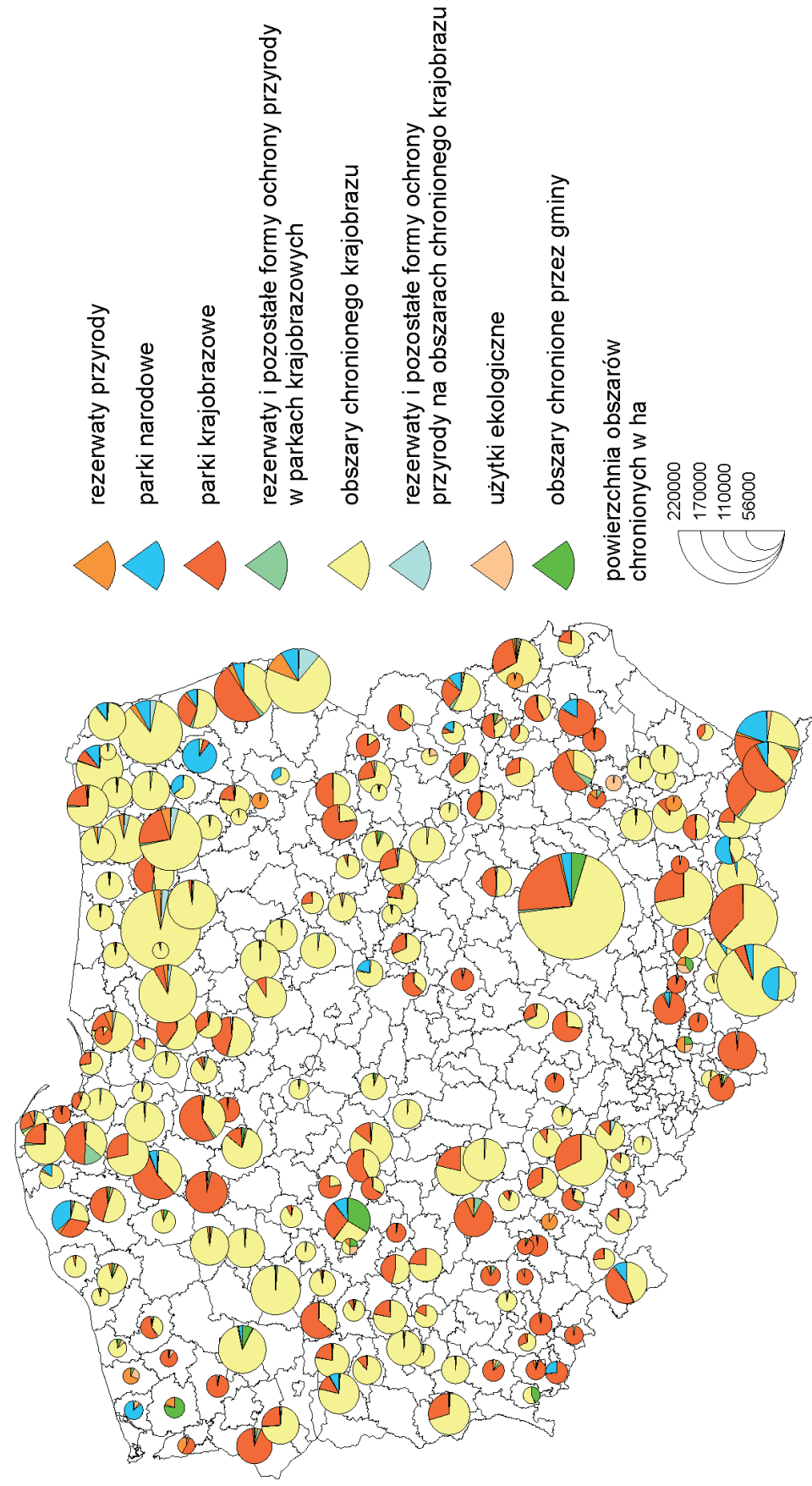
Można tu wymienić między innymi gospodarstwa usytuowane w pobliżu atrakcyjniejszych pod względem turystycznym pasm górskich: Tatr i Pienin (gminy od Czarnego Dunajca i Kościeliska po Czorsztyn i Krościenko nad Dunajcem), Beskidu Sądeckiego ${ }^{1}$ (Krynica-Zdrój, Muszyna). Wysokim poziomem atrakcyjności turystycznej cechują się również gminy północnej części Bieszczadów, Góry Sanocko-Turczańskie i Pogórze Bukowskie oraz wybrane gminy Beskidu Niskiego. Generalnie można powiedzieć, że w województwie małopolskim, podkarpackim i warmińsko-mazurskim znajduje się około 40\% wszystkich gospodarstw agroturystycznych działających Polsce (Turystyka wiejska..., 2012). Ponadto w omawianych regionach rozwój agroturystyki może przyczynić się do zwiększenia poziomu bezpieczeństwa społecznego i zahamowania negatywnych procesów migracyjnych (Raźniak, 2012).

Obszary Polski charakteryzujące się szczególnymi walorami przyrodniczo-kulturowymi w dużej mierze odpowiadają terenom, które cechuje wyższy stopień zagospodarowania turystycznego. Należy tu wymienić głównie tereny górskie, pojezierne i nadmorskie, a także niektóre gminy zlokalizowane w pobliżu dużych aglomeracji miejskich. Innym istotnym wskaźnikiem sprzyjającym rozwojowi agroturystyki jest również sytuacja społeczno-gospodarcza i rozwój infrastruktury turystycznej. Wysoka wartość tego wskaźnika cechuje zazwyczaj gminy usytuowane w pobliżu dużych aglomeracji miejskich i tereny nadmorskie (por. tab. 2).

Tab. 2. Potencjał turystyczny obszarów wiejskich według województw

\begin{tabular}{|l|c|c|c|}
\hline \multirow{2}{*}{ Województwa } & \multicolumn{3}{|c|}{ Wskaźniki } \\
\cline { 2 - 4 } & $\begin{array}{c}\text { Walory } \\
\text { przyrodniczo- } \\
\text {-kulturowe }\end{array}$ & $\begin{array}{c}\text { Zagospodarowanie } \\
\text { turystyczne }\end{array}$ & $\begin{array}{c}\text { Warunki ekonomiczne } \\
\text { i infrastrukturalne }\end{array}$ \\
\hline dolnośląskie & 0,369 & 0,498 & 0,624 \\
\hline kujawsko-pomorskie & 0,363 & 0,250 & 0,368 \\
\hline lubelskie & 0,343 & 0,309 & 0,036 \\
\hline lubuskie & 0,394 & 0,294 & 0,464 \\
\hline łódzkie & 0,328 & 0,141 & 0,279 \\
\hline małopolskie & 0,685 & 0,987 & 0,450 \\
\hline mazowieckie & 0,440 & 0,174 & 0,378 \\
\hline opolskie & 0,295 & 0,150 & 0,364 \\
\hline podkarpackie & 0,659 & 0,625 & 0,275 \\
\hline podlaskie & 0,449 & 0,874 & 0,021 \\
\hline pomorskie & 0,474 & 0,955 & 0,535 \\
\hline śląskie & 0,369 & 0,355 & 0,549 \\
\hline świętokrzyskie & 0,421 & 0,347 & 0,158 \\
\hline warmińsko-mazurskie & 0,468 & 0,932 & 0,175 \\
\hline wielkopolskie & 0,405 & 0,208 & 0,524 \\
\hline zachodniopomorskie & 0,402 & 1,000 & 0,478 \\
\hline
\end{tabular}

Źródło: Turystyka wiejska... (2012)

${ }^{1}$ Według zgromadzonej bazy danych największa liczba gospodarstw agroturystycznych w przeliczeniu na liczbę mieszkańców jest w Tyliczu zlokalizowanym w sąsiedztwie Krynicy-Zdrój. 


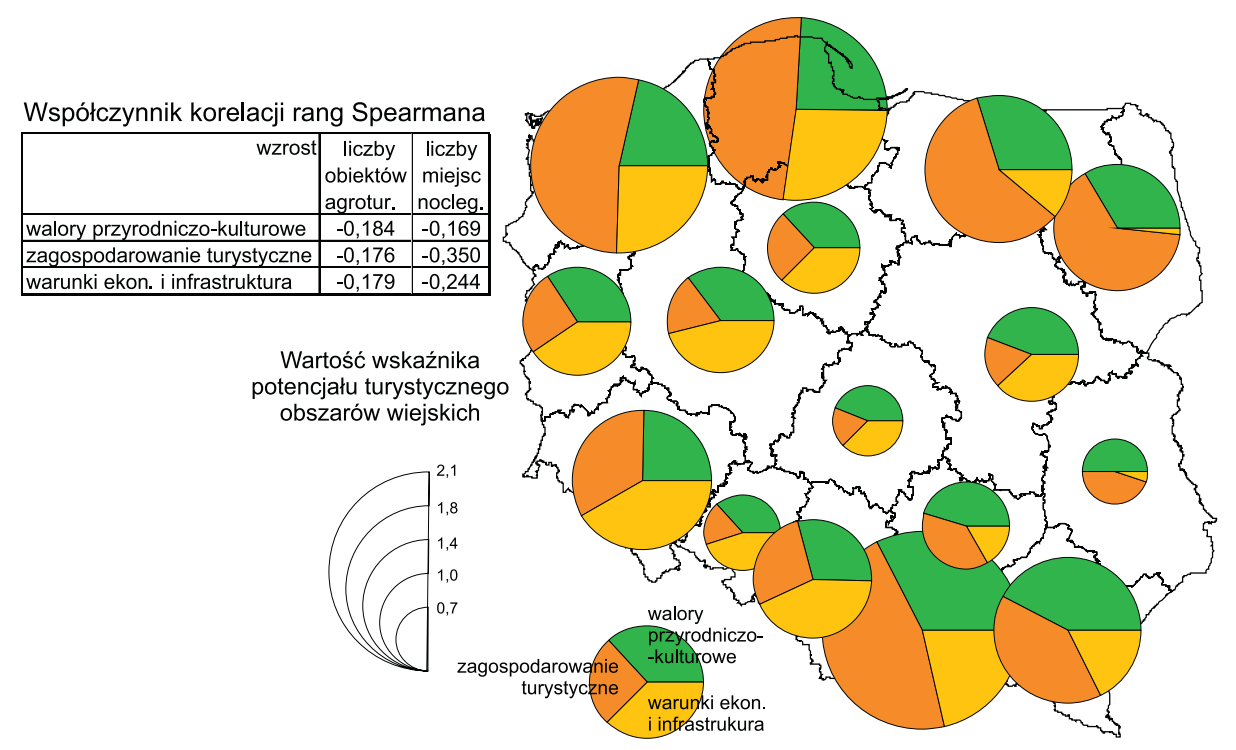

Ryc. 4. Potencjał turystyczny obszarów wiejskich wg województw oraz współczynnik korelacji rang Spearmana

Źródło: opracowanie własne w oparciu o: Turystyka wiejska... (2012: 28)

Analiza korelacji zmian liczebności gospodarstw agroturystycznych (tab. 1.) oraz wartości wskaźników określających potencjał turystyczny obszarów wiejskich wg województw (tab. 2.) wykazała brak zależności (współczynnik korelacji rang Spearmana - ryc. 4). Ujemna wartość korelacji dla wszystkich trzech wskaźników świadczy o braku zależności między lokalizacją kolejnych powstających gospodarstw agroturystycznych a wskaźnikami określającymi walory przyrodniczo-kulturowe $(-0,184$ dla liczby obiektów agroturystycznych, $-0,169$ dla liczby miejsc noclegowych), walory zagospodarowania turystycznego (odpowiednio $-0,176,-0,350)$ oraz warunki ekonomiczno-infrastrukturalne $(-0,179,-0,244)$ poszczególnych województw, w których obiekty te powstają.

Na podstawie powyższego można wnioskować, że choć pierwotnie potencjał turystyczny obszarów wiejskich miał pewne znaczenie w lokalizacji gospodarstw agroturystycznych, dalszy rozwój agroturystyki niekoniecznie powiązany jest w prostej linii z owymi walorami. W dalszej perspektywie to właśnie zachowania przedsiębiorcze właścicieli gospodarstw rolnych, a nie sama lokalizacja owych gospodarstw mają kluczowe znaczenie w podejmowaniu działalności gospodarczej.

\section{OFERTA GOSPODARSTW AGROTURYSTYCZNYCH}

Bezpośrednie badania kwestionariuszowe oraz analiza ofert zamieszczonych na stronach internetowych badanych gospodarstw agroturystycznych umożliwiły dokonanie analizy 
jakości usług świadczonych przez gospodarstwa agroturystyczne. W Polsce świadectwem potwierdzającym poziom jakości kwater wiejskich są słoneczka. Najwyższą kategorią są trzy słoneczka (III), natomiast najniższą kategorią jest „standard” (brak słoneczka). Badania wykazały, że niemal $61 \%$ badanych gospodarstw nie zostało objętych kategoryzacją $\mathrm{WBN}^{2}$, co oznacza, że gospodarstwa nie zdecydowały się na poddanie procesowi kategoryzacji. Nieco ponad $17 \%$ podmiotów miało jedno słoneczko, $15 \%$ dwa słoneczka, a zaledwie $6,5 \%$ trzy słoneczka. Brak standaryzacji ankietowani najczęściej tłumaczyli brakiem korzyści płynących z jej przyjęcia. Niemal 33\% ankietowanych wybrało właśnie tę odpowiedź. Inne argumenty to np.: zbyt wysokie wymagania związane z kategoryzacją $(6,5 \%)$, zbyt zawiła procedura $(4,3 \%)$. Zaledwie około $22 \%$ badanych gospodarstw to gospodarstwa ekologiczne, posiadające odpowiedni certyfikat. Gospodarstwa ekologiczne skupione są na wschodzie Polski, zwłaszcza na Podlasiu i Suwalszczyźnie (ryc. 5).

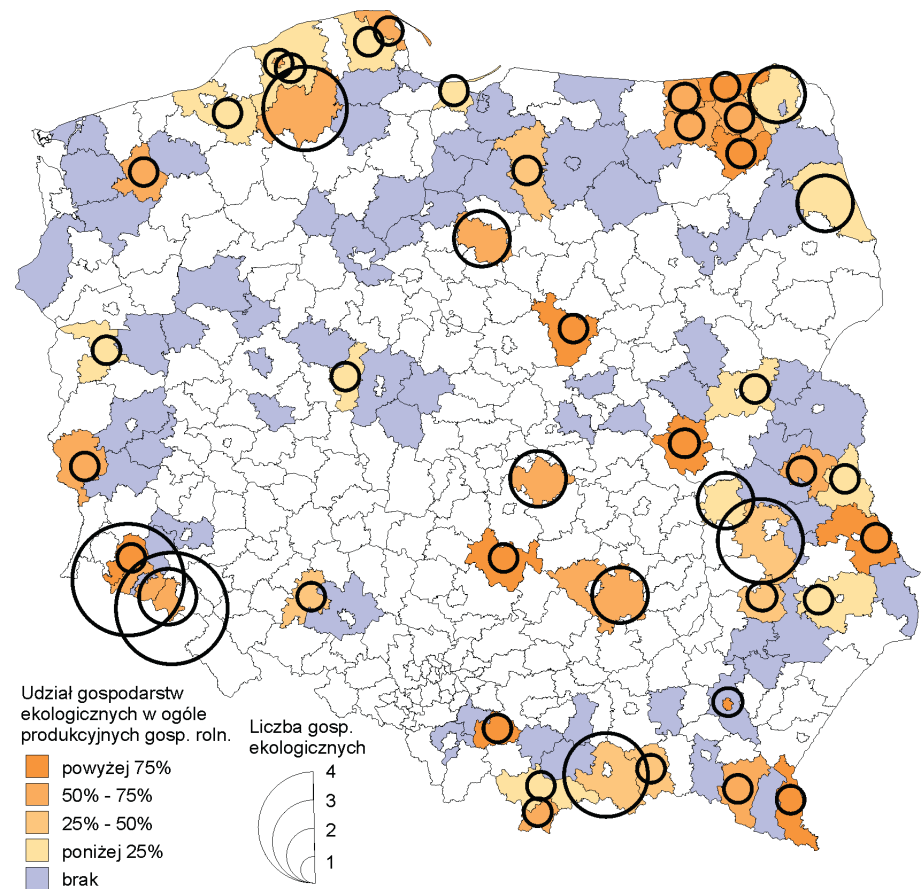

Ryc. 5. Gospodarstwa ekologiczne w Polsce

Źródło: opracowanie własne na podstawie danych internetowych http://agroturystyka.pl (2012)

Ogólnie można stwierdzić, że według rozmieszczenia najwyższy średni standard kwater oferują gospodarstwa na Pomorzu oraz na Warmii i Mazurach (ryc. 6). Wysoki standard

\footnotetext{
${ }^{2}$ Kategoryzacja WBN (Wiejskiej Bazy Noclegowej) polega na nadawaniu obiektom noclegowym określonej kategorii, świadczącej o jakości wyposażenia i oferowanych usług. System jest wzorowany na podobnych systemach kategoryzacji przyjętych w krajach Unii Europejskiej (dla przykładu świadectwem sprawdzonej jakości kwater wiejskich we Francji są kłosy).
} 
oferują również agrogospodarstwa na Dolnym Śląsku i zachodnich pojezierzach Polski. Jednakże we wszystkich regionach Polski można zauważyć duży odsetek gospodarstw nieobjętych kategoryzacją.

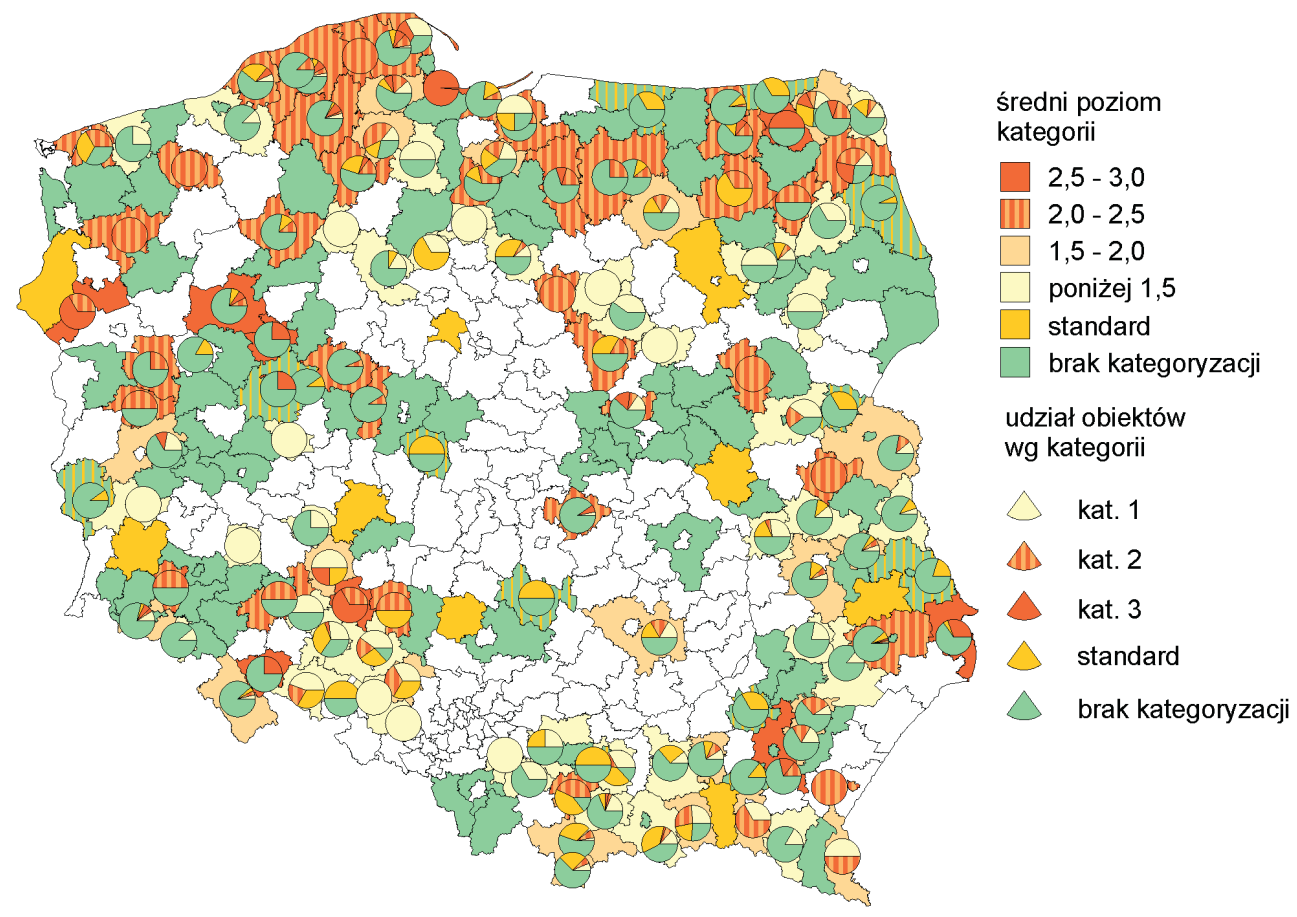

Ryc. 6. Standard ofert agroturystycznych w Polsce

Źródło: opracowanie własne na podstawie danych internetowych http://agroturystyka.pl (2012)

Większość, bo aż prawie 83\% badanych gospodarstw przyjmuje gości przez cały rok. Oferta zazwyczaj kierowana jest do wszystkich zainteresowanych tego typu formą spędzania czasu wolnego (ponad 30\%). Część gospodarstw może jednak pochwalić się dodatkową specjalizacją. Gospodarstwa te są przygotowane na przyjmowanie małżeństw z dziećmi $(19,7 \%)$, pracowników firm $(12,3 \%)$, turystów zagranicznych $(10,7 \%)$ oraz osób starszych (9,8\%). W przypadku wszystkich gospodarstw agroturystycznych uczestniczących w badaniu zadeklarowano zdolność posługiwania się przynajmniej jednym językiem obcym (angielskim $-47,8 \%$, niemieckim $-41,3 \%$, rosyjskim $-43,5 \%$, włoskim $-4,3 \%$, ukraińskim $-4,3 \%$, hiszpańskim $-2,1 \%$ ).

Większość (aż 77\%) badanych gospodarstw agroturystycznych zadeklarowało, że oferowane turystom pokoje gościnne znajdują się w oddzielnym budynku mieszkalnym $(30,8 \%)$ lub w wydzielonej części budynku mieszkalnego zajmowanego przez rodzinę gospodarza (46,2\%). W około $11 \%$ są to pokoje z oddzielną łazienką i WC. W przypadku $12 \%$ badanych gospodarstw gospodarze zapewniają turystom również możliwość korzystania z oddzielnej kuchni lub aneksu kuchennego znajdującego się przy pokoju (10,8\%) lub ze wspólnej kuchni 
z gospodarzami (1,2\%). Dużym atutem jest również pokój dzienny lub sala telewizyjna znajdująca się w ofercie prawie 9\% gospodarstw agroturystycznych. Niemal 17\% badanych gospodarstw udostępnia: pole namiotowe $(9,2 \%)$, pole kempingowe $(6,2 \%)$ lub proponuje pokoje gościnne w domkach kempingowych (1,5\%). Natomiast zaledwie około 5\% badanych gospodarstw dysponuje pokojami gościnnymi na tej samej kondygnacji, na której znajdują się również pokoje rodziny gospodarza.

Dodatkowe udogodnienia dla turystów stanowią:

- miejsce na ognisko/grill (13,8\%),

- parking na terenie posesji $(13,2 \%)$,

- ogród/sad (12\%),

- miejsce zabaw dla dzieci $(10,2 \%)$,

- boisko do gier $(8,3 \%)$.

Najczęściej wymieniane przez gospodarzy atrakcje dla turystów to:

- jazda konna (15,7\%),

- biesiadowanie przy muzyce ludowej $(11,4 \%)$,

- pokazy edukacyjne dla młodzieży $(10,4 \%)$,

- pokazy rękodzielnictwa $(8,9 \%)$,

- połów ryb $(8,9 \%)$,

- grzybobranie $(8,2 \%)$.

Inne, rzadziej wymieniane atrakcje to: leczenie niekonwencjonalne $(6,8 \%)$, zwierzęta gospodarskie/domowe (5,4\%), zwiedzanie okolicy z przewodnikiem $(4,6 \%)$, polowanie lub obserwacja przyrody (4,3\%), możliwość wypożyczania sprzętu sportowego lub rekreacyjnego (rowery, narty, kajaki, leżaki, kije nordic walking itp. $-2,9 \%$ ) oraz kuligi $(0,7 \%)$. Prawie $16 \%$ badanych gospodarstw oferuje pełne wyżywienie, natomiast około $7 \%$ nie prowadzi wyżywienia.

W przekroju przestrzennym najwięcej udogodnień dla klientów oferują gospodarstwa zlokalizowane w regionach północnych, od Mazur po Pomorze Zachodnie, oraz na wschodzie od Podlasia po Bieszczady (ryc. 7). Wyróżniają się pod tym względem również region pojezierzy północno-zachodnich i obszary górskie. Jednakże najwięcej ofert mają gospodarstwa skupione na wschód od Warszawy na obszarach wschodniego Mazowsza i północnej części Lubelszczyzny. Wydaje się, że spowodowane jest to bliskością stolicy i dużymi wymaganiami zamożnych klientów.

Analizując również przestrzenne zróżnicowanie ofert związanych z wypożyczeniem sprzętu sportowego, można zauważyć, że największy odsetek gospodarstw dysponujących taką ofertą skupiony jest we wspominanym regionie północnej Lubelszczyzny oraz w pobliżu stolicy (ryc. 8A). Wysokim odsetkiem gospodarstw z możliwością korzystania ze sprzętu sportowego odznaczają się także obszary Kaszub oraz wschodniej części Wielkopolski i Lubuskie. Sprzęt pozostający do dyspozycji przyjeżdżających to najczęściej rowery oraz sprzęty wodne (głównie kajaki) i narty (również do narciarstwa klasycznego, głównie w regionach nizinnych, co może świadczyć o ich całorocznym funkcjonowaniu) (ryc. 8B). 

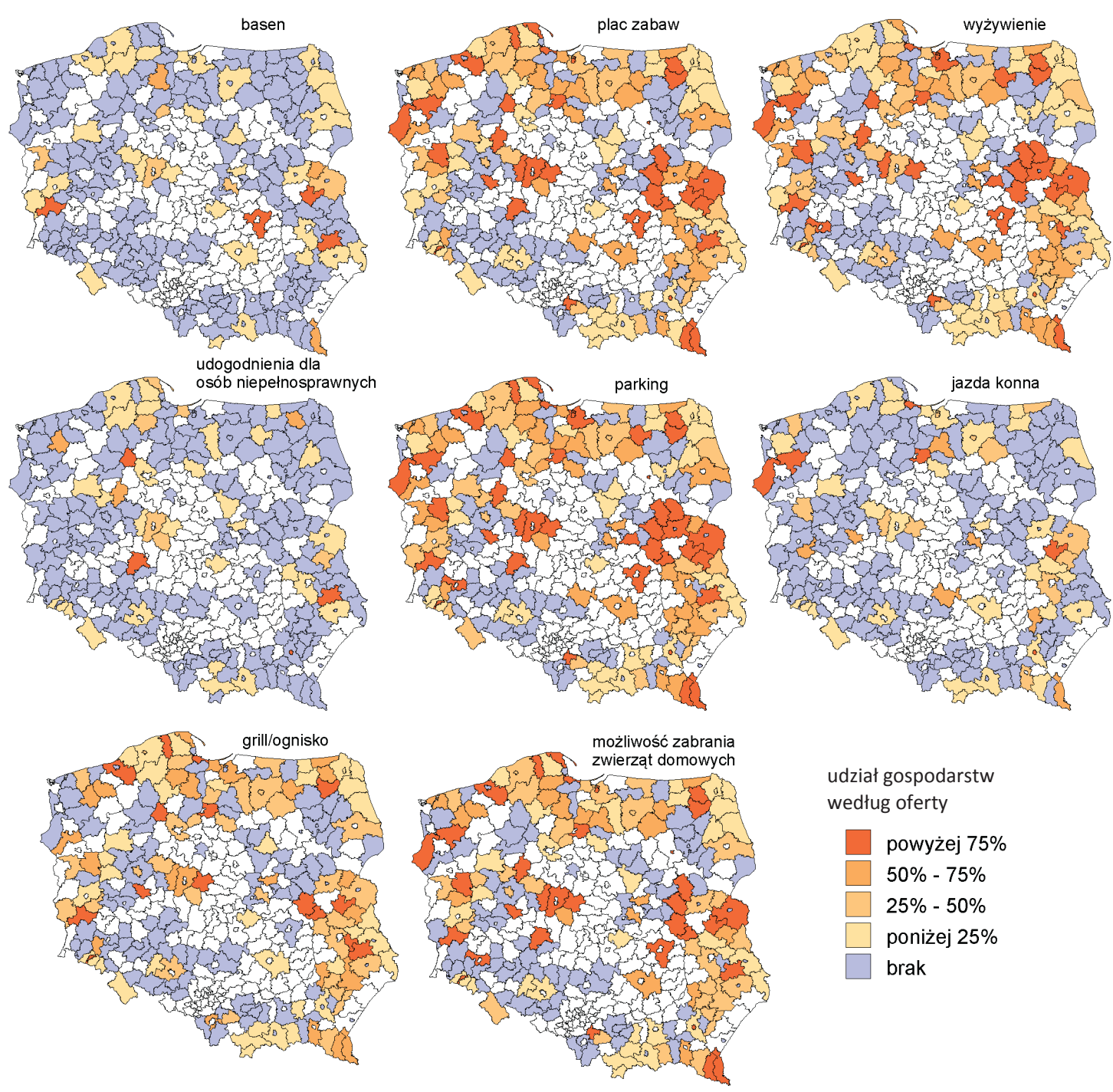
udział gospodarstw według oferty
powyżej $75 \%$
$50 \%-75 \%$
$25 \%-50 \%$
poniżej $25 \%$
brak

Ryc. 7. Wybrane atrakcje w ofertach agroturystycznych w Polsce

Źródło: opracowanie własne na podstawie danych internetowych http://agroturystyka.pl (2012) 

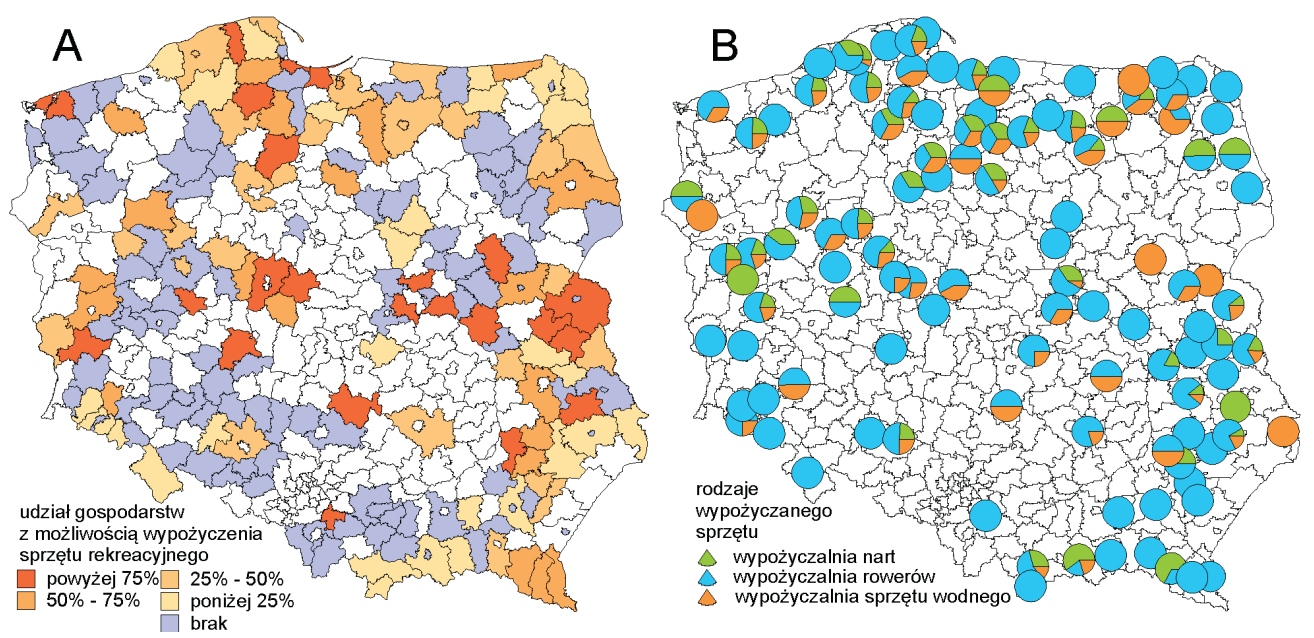

Ryc. 8. Standard ofert agroturystycznych w Polsce

Źródło: opracowanie własne na podstawie danych internetowych http://agroturystyka.pl (2012)

Przedstawiona powyżej analiza struktury ofert gospodarstw agroturystycznych wskazuje, że rośnie popularność propozycji skierowanych do rodzin z dziećmi. Coraz częściej gospodarstwa oferują również infrastrukturę i usługi pozwalające na obsługę klientów instytucjonalnych (np. organizację konferencji czy tzw. zielonych szkół).

\section{TECHNOLOGIE INFORMACYJNE, PROMOCJA I SZKOLENIA W AGROTURYSTYCE}

Gospodarstwa agroturystyczne uczestniczące w bezpośrednich badaniach kwestionariuszowych deklarują, że w dużym stopniu korzystają z technologii informacyjnych, a w szczególności z internetu. Dotyczy to zarówno umieszczania oferty w sieci, jak i obsługi turystów. Działania te sprzyjają łatwiejszemu dostępowi turystów do informacji o ofertach gospodarstw, jak również przyczyniają się do usprawnienia procesu rezerwacji kwater.

Badania wykazały, że w przypadku ponad 63\% gospodarstw agroturystycznych uczestniczących w bezpośrednich badaniach kwestionariuszowych możliwe jest dokonanie rezerwacji on-line. Ponadto niemal wszystkie gospodarstwa agroturystyczne, które uczestniczyły w badaniach, posiadały dostęp do internetu (93,5\%), przy czym należy tu podkreślić, że w przypadku niemal 83\% gospodarstw był to dostęp bezprzewodowy (tzw. Wi-Fi). Ponad 93\% badanych gospodarstw przygotowało własną stronę internetową $(93,5 \%)$ i aktualizowało ją w miarę potrzeb (54,3\%). Przy czym 24\% gospodarstw deklarowało, że aktualizacja przeprowadzana jest częściej niż raz do roku, natomiast w przypadku około $9 \%$ aktualizacja nigdy nie była przeprowadzana. Zazwyczaj gospodarstwa samodzielnie administrują stroną (56,5\%) lub korzystają w tym zakresie z usługi grzecznościowej (19,6\%). Około 22\% gospodarstw korzysta z usług firm specjalizujących się w tej dziedzinie. 
Zebranie danych dotyczących 1682 profili polskich gospodarstw agroturystycznych zrzeszonych i rekomendowanych przez Polską Federację Turystyki Wiejskiej „Gospodarstwo Gościnne" umożliwiło dokonanie przestrzennej analizy rozmieszczenia gospodarstw agroturystycznych dysponujących dostępem do internetu (ryc. 9).

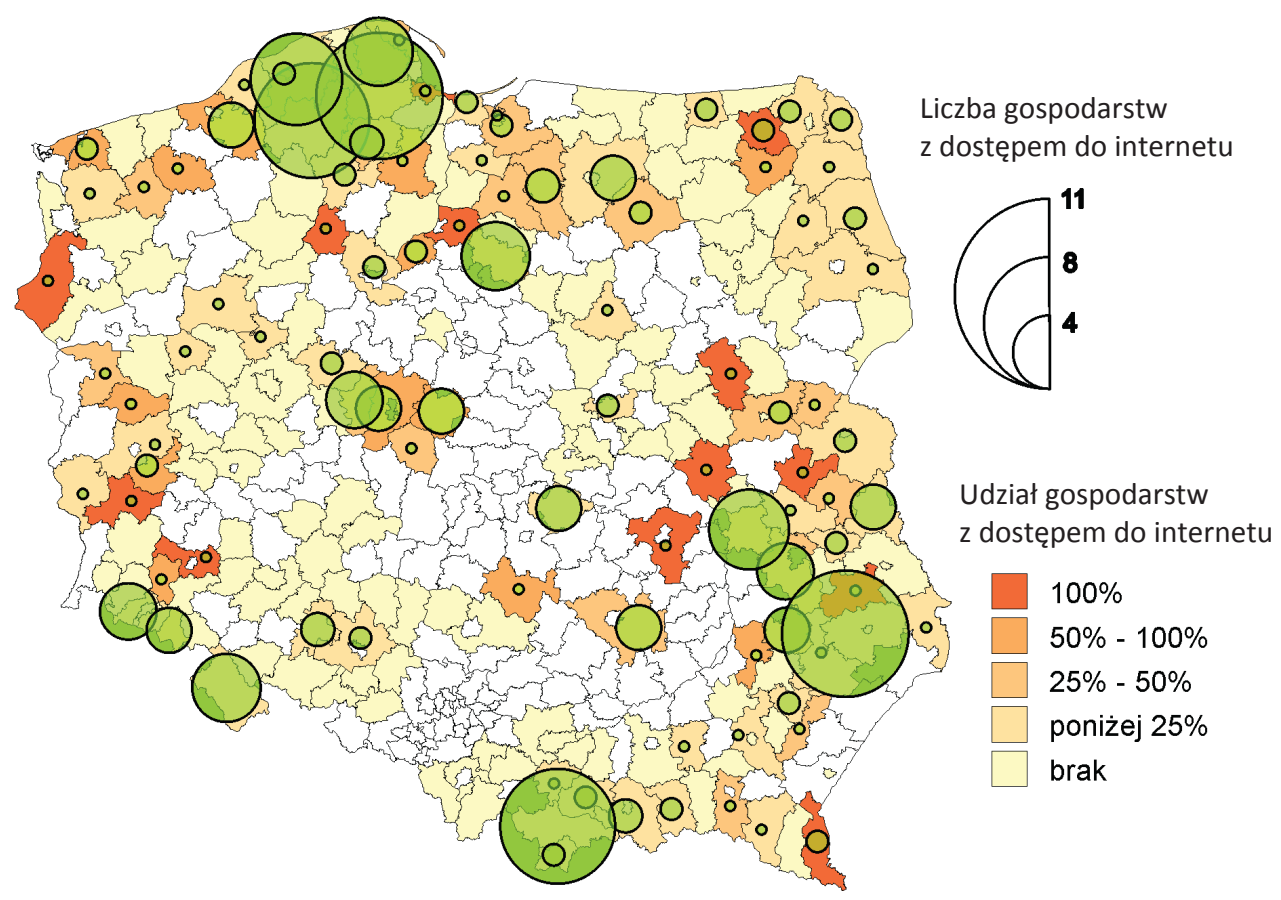

Ryc. 9. Gospodarstwa dysponujące dostępem do internetu

Źródło: opracowanie własne na podstawie danych internetowych http://agroturystyka.pl (2012)

Na rycinie 10 przedstawiono natomiast liczbę oraz usytuowanie gospodarstw agroturystycznych w Polsce, które posiadają własną stronę internetową (ryc. 10A), oraz tych, które ponadto mają własny adres e-mail (ryc. 10B).

Należy tu zwrócić uwagę również na fakt, iż niemal 70\% podmiotów uczestniczących w badaniach kwestionariuszowych potwierdziło, że ich aktywność w sieci nie ogranicza się tylko i wyłącznie do posiadania strony internetowej. Gospodarstwa starają się wykorzystać możliwości, jakie daje im internet, również dla celów promocyjnych, m.in. umieszczając reklamy na specjalnych stronach WWW $(69,6 \%)$, zakładając profile na portalach społecznościowych $(21,7 \%)$, zamieszczając banery i ogłoszenia w lokalnych serwisach internetowych $(15,2 \%)$ czy wykorzystując mailing $(6,5 \%)$. Działania te potwierdzają innowacyjne podejście dużej części podmiotów uczestniczących w badaniach w zakresie wykorzystywanych narzędzi promocji (tab. 3). 

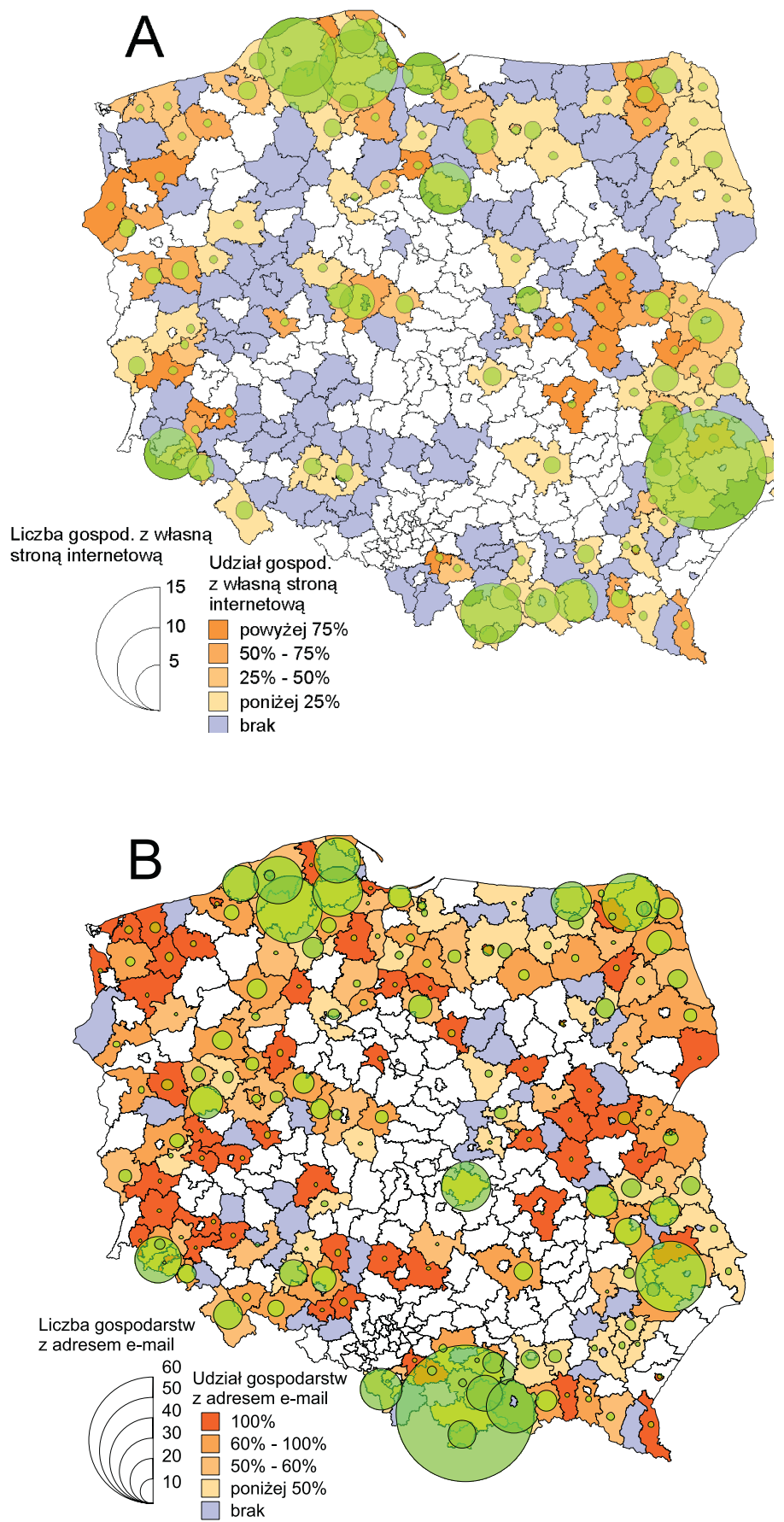

Ryc. 10. Gospodarstwa posiadające własną stronę internetową (A) oraz adres e-mail (B) Źródło: opracowanie własne na podstawie danych internetowych http://agroturystyka.pl (2012) 
Niestety, w zdecydowanej większości infrastruktura badanych gospodarstw nie jest dostosowana do przyjmowania osób niepełnosprawnych. Fakt ten potwierdziło niemal 83\% gospodarstw, które uczestniczyły w badaniu.

Ponad 54\% badanych zadeklarowało, że sprawdza stopień zadowolenia klientów z usług gospodarstwa, przy czym prawie $37 \%$ robi to tylko okazjonalnie, zaś tylko nieco ponad $17 \%$ regularnie. Najczęstszą formą owej kontroli jest rozmowa z klientami. Aż niemal 70\% z tych gospodarstw, które w jakikolwiek sposób sprawdzają poziom zadowolenia swoich klientów, stosuje właśnie tę metodę kontroli. Jedynie 13\% gospodarstw przeprowadza ankietę wśród klientów.

Badani w większości zapewniają, że poszerzają swoją wiedzę z zakresu turystyki i agroturystyki. Tego typu deklarację złożyło aż 91\% z nich. Również 91\% badanych potwierdziło, że szkolą się regularnie. Na własny koszt i na własną rękę podejmuje edukację 39\% respondentów, a niemal 24\% uczestniczy w szkoleniach organizowanych przez samorząd.

Tab. 3. Instrumenty promocji stosowane przez gospodarstwa agroturystyczne

\begin{tabular}{|l|r|c|}
\hline \multicolumn{1}{|c|}{$\begin{array}{c}\text { Odpowiedzi respondentów } \\
\mathrm{N}=46\end{array}$} & Liczność & $\begin{array}{c}\text { Procent } \\
\text { przypadków* }\end{array}$ \\
\hline Plakaty, bilbordy & 8 & 17,4 \\
\hline Ulotki, foldery & 34 & 73,9 \\
\hline Ogłoszenia w prasie, radiu, telewizji, w tym: & 12 & 26,1 \\
o zasięgu lokalnym & 7 & 15,2 \\
o zasięgu krajowym & 5 & 10,9 \\
za granicą & 0 & 0,0 \\
\hline Reklamy na specjalnych stronach WWW & 35 & 76,1 \\
\hline Wysyłanie e-maili promocyjnych & 3 & 6,5 \\
\hline Profil na portalach społecznościowych (np. Facebook) & 10 & 21,7 \\
\hline Banery i ogłoszenia w lokalnych serwisach internetowych & 7 & 15,2 \\
\hline Obniżka cen & 10 & 21,7 \\
\hline Specjalne oferty dla stałych klientów & 22 & 47,8 \\
\hline Upominki lub usługi (tzw. gratisy) dla gości & 18 & 39,1 \\
\hline Prezentacja oferty gospodarstwa na lokalnych imprezach & 18 & 39,1 \\
\hline Prezentacja oferty gospodarstwa na targach turystycznych & 26 & 56,5 \\
\hline Przynależność do stowarzyszeń i organizacji turystycznych & 37 & 80,4 \\
\hline Inne & 2 & 4,3 \\
\hline Brak podejmowanych działań w tym kierunku & 1 & 2,2 \\
\hline
\end{tabular}

*Każdy z respondentów mógł udzielić większej liczby odpowiedzi, dlatego też suma wartości w kolumnie procentowej nie jest równa 100.

Źródło: Dorocki, Szymańska, Zdon-Korzeniowska (2012: 55-56)

Gospodarstwa uczestniczące w badaniu twierdzą, iż starają się być innowacyjne. Aż $63 \%$ badanych przedsiębiorstw agroturystycznych zadeklarowało, że w ubiegłym roku wprowadzono jakąś nowość. Niestety, w kwestionariuszu nikt z badanych nie określił, jakie to były innowacje. Pomysły na rozszerzanie działalności są zazwyczaj efektem sugestii gości $(36,4 \%)$, obserwacji działalności innych gospodarstw $(24,2 \%)$ lub stanowią pomysły własne 
albo członków rodziny (24,2\%). Zaledwie 3,0\% ogółu stanowią pomysły zaczerpnięte ze szkoleń, w których uczestniczą pracownicy przedsiębiorstw agroturystycznych.

\section{ZAKOŃCZENIE}

Zasadnicze znaczenie w zakresie budowy gospodarki opartej na wiedzy ma proces nabywania, przetwarzania i upowszechniania wiedzy. Wiedza staje się tu kluczowym czynnikiem produkcji i źródłem przewagi konkurencyjnej. Znaczenie tego czynnika w budowaniu swojej pozycji rynkowej niewątpliwie dostrzegają duże korporacje, w tym również turystyczne. W odniesieniu do mikro, małych i średnich przedsiębiorstw turystycznych, w tym gospodarstw agroturystycznych, sprawa nie jest już tak oczywista. Tu świadomość i zdolność wykorzystywania wiedzy jako źródła tworzenia przewagi konkurencyjnej są znacznie niższe. Z deklaracji badanych gospodarstw agroturystycznych wynika, że stale poszerzają one swoją wiedzę turystyczną. Agrobiznesmeni regularnie szkolą się z zakresu turystyki i agroturystyki. Prawdopodobnie jednak rozszerzeniu ulec powinien zakres nabywanej wiedzy i sposób jej wykorzystania, gdyż, jak zauważają K. Perechuda i D. Hołodnik (2012: 36), „nowoczesne koncepcje, modele i metody zarządzania są praktycznie nieznane właścicielom gospodarstw agroturystycznych, które mają przede wszystkim charakter firm rodzinnych i zarządzane są na zasadzie intuicyjnej”.

Z przeprowadzonych analiz wynika, że badane gospodarstwa stale poszerzają ofertę, uwzględniając opinie i preferencje swoich klientów oraz zapotrzebowanie zgłaszane przez rynek. Ponieważ jednak oferta pojedynczego gospodarstwa agroturystycznego jest tylko częścią całościowego produktu agroturystycznego danego obszaru, dla oferowania wysokiej jego jakości niezbędna jest współpraca wielu podmiotów, wśród których szczególną rolę odgrywają samorządy terytorialne. Ich aktywna postawa na rzecz wspierania rozwoju turystyki na danym obszarze oraz tworzenie klimatu dla przedsiębiorczości są ważnymi czynnikami w zakresie budowy gospodarki turystycznej opartej na wiedzy. Ponadto, jak zauważa M. Kachniewska (2012: 31), poziom konkurencyjności miejsc i regionów turystycznych, a co za tym idzie oferowanych na ich obszarze zintegrowanych produktów turystycznych, „w dużej mierze zależy od rozwoju gospodarki sieciowej lub klastrów turystycznych, przy współudziale różnorodnych podmiotów i kształtowaniu partnerstwa publiczno-prywatnego".

Ważnym czynnikiem wspomagającym rozwój GOW jest również wykorzystywanie zaawansowanych technologii informatycznych i komunikacyjnych. W przypadku badanych gospodarstw agroturystycznych sprowadza się to w dużej mierze jedynie do posiadania i administrowania stronami WWW. Deklarowane przez agrobiznesmenów rezerwacje on-line dokonują się również raczej za pomocą wykorzystania poczty e-mail niż poprzez zastosowanie profesjonalnych systemów rezerwacyjnych. Badane gospodarstwa coraz częściej zdają się dostrzegać szersze i bardziej aktywne sposoby wykorzystania internetu w działaniach związanych z promocją (np. posiadanie profilu na portalach społecznościowych). Zakres wykorzystania zaawansowanych technologii w gospodarstwach agroturystycznych jest jednak 
niewielki. Jak wskazuje M. Kachniewska (2012: 22), „funkcjonowanie w warunkach gospodarki cyfrowej wymaga uzupełnienia niedostatków wiedzy z dwóch obszarów: po pierwsze znajomości technologii, które mogą mieć zastosowanie we współczesnej działalności gospodarczej, a w szczególności obsłudze rynku turystycznego; po drugie zaś wiedzy na temat prawidłowego wykorzystania tych technologii w celu poprawy jakości i efektywności działania oraz własnej konkurencyjności”. W warunkach globalizacji, zanikania barier związanych z możliwością docierania do najbardziej odległych miejsc i w dobie internetu turystyka jawi się jako jedna z dziedzin silniej uzależnionych od dostępu do sieci i wykorzystania nowych technologii.

\section{Literatura}

Borowiec, M., Dorocki, S., Jenner, B. (2009). Wpływ zasobów kapitału ludzkiego na kształtowanie społeczeństwa informacyjnego i innowacyjności struktur przemysłowych. Prace Komisji Geografii Przemystu Polskiego Towarzystwa Geograficznego, 13, 95-109.

Chojnicki, Z., Czyż, T. (2007). Rola kapitału ludzkiego w kształtowaniu gospodarki opartej na wiedzy w Polsce. Przegląd Geograficzny, 79, 423-438.

Dorocki, S., Szymańska, A.I., Zdon-Korzeniowska, M. (2012). Polskie gospodarstwa agroturystyczne jako przedsiębiorstwa rodzinne. Przedsiębiorczość i Zarządzanie, 8(8), 45-60.

Dorocki, S., Zdon-Korzeniowska, M. (2013). Rozwój agroturystyki jako formy dywersyfikacji działalności rolniczej-przykład Polski i Francji (w druku).

Dorocki, S., Szymańska, A.I., Rachwał, T., Zdon-Korzeniowska, M., (2013a). Spatial Conditions for Agritourism Development on the Example of Poland and France. Current Issues of Tourism Research, 2, 20-29.

Dorocki, S., Szymańska, A.I., Zdon-Korzeniowska, M. (2013b). Gospodarstwa agroturystyczne w dobie kryzysu gospodarczego. Przedsiębiorczość - Edukacja, 9 (w druku).

Fic, M. (2005). Gospodarka oparta na wiedzy. W: D. Kopycińska (red.). Teoretyczne aspekty gospodarowania. Szczecin: Katedra Mikroekonomii Uniwersytetu Szczecińskiego.

Jagusiewicz, A., Legienis, H. (2006). Zasoby bazy noclegowej indywidualnego zakwaterowania w Polsce w 2006 roku. Warszawa: Instytut Turystyki.

Kachniewska, M. (2012). Internetowe platformy upowszechniania wiedzy jako narzędzie poprawy konkurencyjności przedsiębiorstw i regionów turystycznych. W: M. Morawski (red.). Zarzadzanie wiedza w turystyce a efektywność gospodarki turystycznej. Wrocław: Akademia Wychowania Fizycznego we Wrocławiu.

Kłodziński, M. (2001). Bariery i priorytety w rozwoju przedsiębiorczości wiejskiej. Zeszyty Naukowe Akademii Rolniczej im. H. Koltątaja w Krakowie, 1(78), 215-226.

Niklewicz-Pijaczyńska, M. (2011). Od koncepcji gospodarki opartej na wiedzy do strategii rozwoju UE 2020. W: J. Kundera (red.). Globalizacja, europejska integracja a kryzys gospodarczy. Wrocław: Wydział Prawa Administracji i Ekonomii Uniwersytetu Wrocławskiego, 444-445.

Perechuda, K., Hołodnik, D. (2012). Nowoczesny model gospodarstwa agroturystycznego oparty na wiedzy. W: M. Morawski (red.). Zarządzanie wiedza w turystyce a efektywność gospodarki turystycznej. Wrocław: Akademia Wychowania Fizycznego we Wrocławiu.

Rachwał, T., Zdon-Korzeniowska, M. (2011). Turystyka w warunkach światowego kryzysu gospodarczego. Prace Komisji Geografii Przemystu Polskiego Towarzystwa Geograficznego, 18, 116-128.

Raźniak P. (2012). Wpływ poziomu bezpieczeństwa społecznego na migracje ludności w Polsce. W: Bezpieczeństwo. Teoria i Praktyka, 4/2012, Kraków: Oficyna Wydawnicza AFM, 41-52. 
Sikora, J. (2012). Agroturystyka. Przedsiębiorczość na obszarach wiejskich. Warszawa: Wydawnictwo C.H. Beck.

Turystyka wiejska, w tym agroturystyka,jako element zrównoważonego i wielofunkcyjnego rozwoju obszarów wiejskich (2012). Warszawa: Agrotec Polska Sp. z o.o., Instytut Geografii i Przestrzennego Zagospodarowania im. Stanisława Leszczyckiego PAN (IGiPZ PAN).

Wiatrak, A.P. (2003). Baza agroturystyczna w Polsce i uwarunkowania jej rozwoju. Zeszyty Naukowe Akademii Rolniczej im. H. Kołłątaja w Krakowie, 90, 9-18.

Sławomir Dorocki, dr, Uniwersytet Pedagogiczny w Krakowie, Instytut Geografii, Zakład Przedsiębiorczości i Gospodarki Przestrzennej.

Absolwent studiów z zakresu geografii społeczno-ekonomicznej Uniwersytetu Pedagogicznego w Krakowie, doktor nauk humanistycznych w dyscyplinie historia (Instytut Europeistyki Uniwersytet Jagielloński). Adiunkt w Instytucie Geografii Uniwersytetu Pedagogicznego w Krakowie. Zainteresowania badawcze skupiają się wokół problematyki regionów i procesów regionalizacji społeczno-gospodarczej, ze szczególnym uwzględnieniem zróżnicowania przestrzeni europejskiej oraz procesów integracji europejskiej i uwarunkowań historycznych.

Sławomir Dorocki, graduated from Pedagogical University of Cracow, MA degree in geography, Ph.D. in history (Institute of European Studies of the Jagiellonian University). Adjunct (assoc. professor) at Pedagogical University of Cracow, Institute of Geography. His research interests are tied with regional problems and processes of socio-economic regionalization, with particular emphasis on the diversity of Europe, processes of European integration and historical conditions.

Anna Irena Szymańska, dr, Uniwersytet Pedagogiczny w Krakowie, Instytut Geografii, Zakład Przedsiębiorczości i Gospodarki Przestrzennej.

Absolwentka studiów magisterskich z zakresu zarządzania i marketingu Uniwersytetu Ekonomicznego w Krakowie, doktor nauk ekonomicznych w zakresie nauk o zarządzaniu (Katedra Analizy Rynku i Badań Rynkowych - Uniwersytet Ekonomiczny w Krakowie). Adiunkt w Zakładzie Przedsiębiorczości i Gospodarki Przestrzennej Uniwersytetu Pedagogicznego w Krakowie. Jej zainteresowania naukowo-badawcze oscylują wokół problematyki potrzeb, preferencji i zachowań rynkowych konsumentów, jak również zagadnień z obszaru przedsiębiorczości i innowacyjności przedsiębiorstw ze szczególnym uwzględnieniem sektora MŚP.

Anna Irena Szymańska, graduated from Cracow University of Economics, MA degree in Management and Marketing, $\mathrm{PhD}$ degree in economic sciences in the field of management sciences (Chair of Market Analysis and Marketing Research - Cracow University of Economics). Adjunct (assoc. professor) in the Department of Entrepreneurship and Spatial Management at Pedagogical University of Cracow. Her research interests are related to the issue of consumer needs, preferences and market behaviour as well as issues in the area of entrepreneurship and innovation with particular emphasis on the SME sector.

Małgorzata Zdon-Korzeniowska, dr, Uniwersytet Pedagogiczny w Krakowie, Instytut Geografii, Zakład Przedsiębiorczości i Gospodarki Przestrzennej.

Absolwentka studiów magisterskich Uniwersytetu Ekonomicznego w Krakowie (kierunek: ekonomia, specjalność: przedsiębiorczość i innowacje), doktor nauk ekonomicznych w dyscyplinie nauk o zarządzaniu (Wydział Zarządzania i Komunikacji Społecznej Uniwersytetu Jagiellońskiego). Adiunkt w Zakładzie Przedsiębiorczości i Gospodarki Przestrzennej Instytutu Geografii Uniwersytetu Pedagogicznego w Krakowie. Zainteresowania naukowo-badawcze ogniskują się wokół problematyki zarządzania turystyką na poziomie lokalnym i regionalnym, ze szczególnym uwzględnieniem zrównoważonego rozwoju i budowy produktów turystycznych o charakterze lokalnym i regionalnym, a także 
integracji i koordynacji działań podmiotów zaangażowanych w ten proces, ze szczególnym uwzględnieniem roli samorządu terytorialnego.

Malgorzata Zdon-Korzeniowska, graduated from Cracow University of Economics (Department of Economics, specializing in Entrepreneurship and Innovation), MA degree in economy, Ph.D. in economic sciences in the discipline of management studies (Faculty of Management and Social Communication, Jagiellonian University). Adiunkt (assoc. professor) at Pedagogical University of Cracow, Institute of Geography, Department of Entrepreneurship and Spatial Management. Her research interests centered around the issues of tourism management at the local and regional level, with particular emphasis on sustainable development and the construction of local and regional tourist products, as well as the integration and coordination of the actors involved in this process, with particular emphasis on the role of local government.

adres/address: Uniwersytet Pedagogiczny w Krakowie

Instytut Geografii, Zakład Przedsiębiorczości i Gospodarki Przestrzennej

ul. Podchorążych 2, 30-084 Kraków, Polska

e-mail: sdorocki@up.krakow.pl (Sławomir Dorocki)

aszym@up.krakow.pl (Anna Irena Szymańska)

mkorzen@up.krakow.pl (Małgorzata Zdon-Korzeniowska) 